ARTICLE

https://doi.org/10.1038/s41467-019-10928-0

\title{
Direct electrochemical oxidation of alcohols with hydrogen evolution in continuous-flow reactor
}

\author{
Dan Wang ${ }^{1}$, Pan Wang ${ }^{1}$, Shengchun Wang ${ }^{1}$, Yi-Hung Chen (i) ${ }^{1}$, Heng Zhang ${ }^{1} \&$ Aiwen Lei ${ }^{1}$
}

Alcohol oxidation reactions are widely used for the preparation of aldehydes and ketones. The electrolysis of alcohols to carbonyl compounds have been underutilized owing to low efficiency. Herein, we report an electrochemical oxidation of various alcohols in a continuousflow reactor without external oxidants, base or mediators. The robust electrochemical oxidation is performed for a variety of alcohols with good functional group tolerance, high efficiency and atom economy, whereas mechanistic studies support the benzylic radical intermediate formation and hydrogen evolution. The electrochemical oxidation proves viable on diols with excellent levels of selectivity for the benzylic position.

\footnotetext{
${ }^{1}$ The Institute for Advanced Studies (IAS), College of Chemistry and Molecular Sciences, Wuhan University, 430072 Wuhan, Hubei, People's Republic of China. Correspondence and requests for materials should be addressed to Y.-H.C. (email: yihungchen@whu.edu.cn) or to H.Z. (email: hengzhang@whu.edu.cn) or to A.L. (email: aiwenlei@whu.edu.cn)
} 
A ldehydes or ketones are not only essential functionalities of various biologically active compounds, but also important reagents in modern organic synthesis ${ }^{1,2}$. In fact, the high frequently used of alcohol oxidations to carbonyl compounds leading to a ranking of 3rd of strongly prefer better reagents for pharmaceutical manufacturers ${ }^{3}$. So, developing oxidation of alcohols under environmentally benign and economic conditions is highly demanded ${ }^{4-7}$ for pharmaceutical and chemical industries. Stoichiometric oxidants such as chromium, manganese, and ruthenium salts ${ }^{8-15}$ are relatively not environmental friendly (Fig. 1a). Molecular oxygen, air, or hydrogen peroxide in combination with appropriate transition metal catalysts $\left(\mathrm{Cu}, \mathrm{Ru}, \mathrm{Pd}, \mathrm{Au}, \mathrm{Fe}, \mathrm{V}\right.$, or Ir) ${ }^{16-22}$ represent superior alternatives according to the principles of green and sustainable chemistry. However, the oxidation remains challenging for a broad group of alcohols. In contrast, oxidant-free alcohol oxidation with hydrogen evolution is apparently an ideal process to reach the higher atom economy (Fig. 1b). This concept has been achieved with transition metal catalysis ${ }^{23-30}$, which normally involves expensive transition metals, sophisticated ligands, and generally requires high reaction temperatures. On the other hand, alcohol oxidation with hydrogen release via photocatalysis ${ }^{31,32}$ or electrocatalysis ${ }^{33-40}$ have the merit of running reactions under mild conditions.

Direct electrolysis of alcohols to carbonyl compounds is an idealized goal, which produces only hydrogen without product contamination. The direct electro-oxidation of alcohol can be tracked back to the pioneering work of Lund and Mayeda et al. ${ }^{41-43}$ using undivided electrolysis cells. However, prior attempts gave only the desired aldehydes or ketones in low selectivity and efficiency. We envisioned that electrolysis in a continuous-flow set-up would be a sustainable method to replace

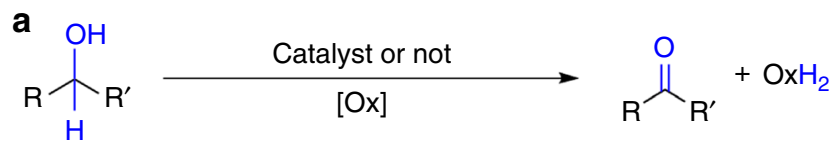

b
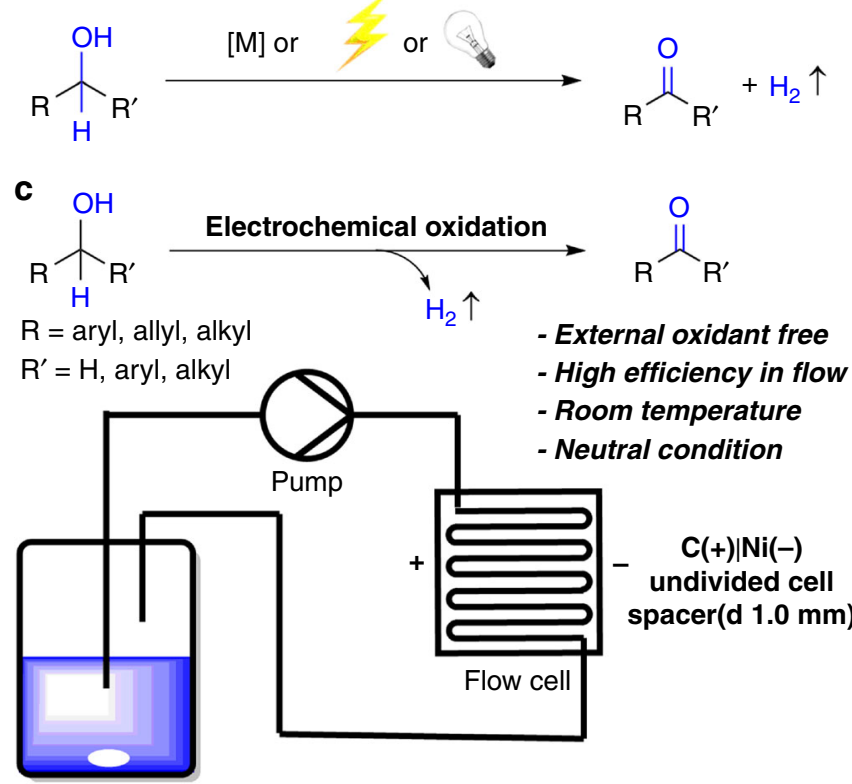

Fig. 1 Alcohol oxidation conditions. a Alcohols oxidation with oxidant. b Alcohols oxidation with dehydrogenation. c Alcohol oxidation under continuous-flow set-up stoichiometric oxidants and improve both energy efficiency and productivity. Large surface-to-volume ratio, enhanced mass transfer, operation at quasi-isothermal condition, and lower resistances are the advantages of using flow electrochemistry setup, which often make it superior than batch mode ${ }^{44-46}$. In addition, the electrode surface can be regenerated efficiently to avoid low conductivity for the transformations with gas evolution. Furthermore, flow cells are easy to scale up and employed in industry $47-49$. Recently, electrochemical flow cells have been successfully used in a variety of organic transformations ${ }^{50-64}$. Herein, we report the direct electrolysis of alcohols to afford the aldehydes or ketones with high efficiency without any mediators or catalysts under neutral conditions by using a flow reactor (Fig. 1c and Supplementary Fig. 1).

\section{Results}

Investigation of reaction conditions. Our studies commenced with benzyl alcohol (1aa), which was subjected to a batch condition in an undivided cell (Table 1, entry 1), yielding $37 \%$ of benzaldehyde (2aa) at $100 \mathrm{~mA}$ constant current electrolysis for 1 h (Supplementary Fig. 2). In order to improve the solubility of the starting material, $\mathrm{CH}_{3} \mathrm{CN}$ and water (1:1) were used as solvents in the continuous-flow set-up, and benzaldehyde (2aa) was isolated in $93 \%$ yield under the same current $(10 \mathrm{~mA}, 10 \mathrm{~h}$, Table 1, entry 2). Encouraged by these results, we investigated the magnitude of current from $10 \mathrm{~mA}$ to $1000 \mathrm{~mA}$ (entries 2-8). When $50 \mathrm{~mA}$ was applied for the oxidation, $92 \%$ of benzaldehyde was isolated in $2 \mathrm{~h}$ (Table 1, entry 3 ). Among a set of studies, 800 $\mathrm{mA}$ enabled effective oxidation up to $99 \%$ yield in $10 \mathrm{~min}$ (Table 1, entry 7). However, when the current was increased to $1000 \mathrm{~mA}$, 2aa was provided in lower yield (81\%, entry 8). The flow rate was another parameter, which was evaluated at the current of $800 \mathrm{~mA}$. Accordingly, $0.10 \mathrm{~mL} \mathrm{~s}^{-1}$ was the optimum flow rate (Table 1, entries 9-11). Then the reaction conditions of $800 \mathrm{~mA}, 10 \mathrm{~min}$ and $0.10 \mathrm{~mL} \mathrm{~s}^{-1}$ were employed for the further researches.

At the flow rate of $0.10 \mathrm{~mL} \mathrm{~s}^{-1}$, the solution passed through the flow cell multiple times by using peristaltic pump. We think that it would be possible to achieve full conversion by employing large current and small flow rate. By using this strategy, the $2 \mathrm{mmol}$ benzyl alcohol in $30 \mathrm{~mL}$ mixed solvent could be quantitatively transformed to benzyaldehyde at $800 \mathrm{~mA}$ and $0.02 \mathrm{~mL} \mathrm{~s}^{-1}$ in $25 \mathrm{~min}$ (Fig. 2a and Supplementary Fig. 3). Furthermore, the reaction scale can be extended to $100.0 \mathrm{mmol}$ at the same current and the flow rate still in quantitative yield (Fig. $2 b$ and Supplementary Fig. 4). These results illustrated the potential applicability of this method.

Substrate scope. With the optimized reaction conditions in hand, we next explored various benzylic and allylic alcohols 1ab-1ap (2.0 mmol) under galvanostatic conditions (Fig. 3). Electron-rich benzylic alcohols with ortho-, meta-, and para-substitution could be converted to the corresponding aldehydes $\mathbf{2 a b}-\mathbf{2} \mathbf{a h}$ in nearly quantitative yields (96-99\%) without over oxidation. Halogenated benzylic alcohols could be oxidized to afford the corresponding aldehydes 2ai-2ak in excellent yield (98-99\%), which could be further functionalized. Owing to weak C-I bond, $10 \mathrm{~mA}$ cell current had to be adapted and 4-iodo benzaldehyde (2al) was obtained in moderate yield (60\%). Moreover, electron-deficient benzylic alcohols gave less satisfactory results. For example, compound 2am was obtained in only 35\% yield. On the other hand, 1-naphthyl methanol (1an) was converted to the corresponding aldehyde 2 an in $88 \%$ yield. The flow conditions could also be applied to thiophene derivative 1 ao to afford aldehyde $\mathbf{2 a o}$ in $76 \%$ yield without significant side product formation. 


\section{Table 1 Optimization of electrochemical oxidation of benzyl alcohol 1aa}

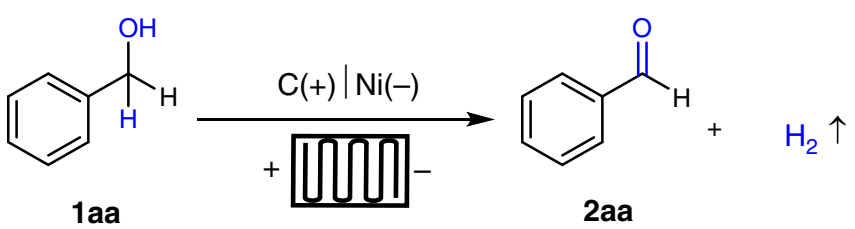

\begin{tabular}{|c|c|c|c|c|c|}
\hline Entry & Current & Reaction time & Current density & Flow rate & Yield $(\%)^{a}$ \\
\hline $1^{b}$ & $100 \mathrm{~mA}$ & $1 \mathrm{~h}$ & $44.44 \mathrm{~mA} \mathrm{~cm}^{-2}$ & Undivided cell & 37 \\
\hline 2 & $10 \mathrm{~mA}$ & $10 \mathrm{~h}$ & $0.64 \mathrm{~mA} \mathrm{~cm}^{-2}$ & $0.10 \mathrm{~mL} \mathrm{~s}^{-1}$ & 93 \\
\hline 3 & $50 \mathrm{~mA}$ & $2 \mathrm{~h}$ & $3.19 \mathrm{~mA} \mathrm{~cm}^{-2}$ & $0.10 \mathrm{~mL} \mathrm{~s}^{-1}$ & 92 \\
\hline 4 & $100 \mathrm{~mA}$ & $1 \mathrm{~h}$ & $6.38 \mathrm{~mA} \mathrm{~cm}^{-2}$ & $0.10 \mathrm{~mL} \mathrm{~s}^{-1}$ & 89 \\
\hline 5 & $500 \mathrm{~mA}$ & $12 \min$ & $31.89 \mathrm{~mA} \mathrm{~cm}^{-2}$ & $0.10 \mathrm{~mL} \mathrm{~s}^{-1}$ & 90 \\
\hline 6 & 800 mA & $8 \min$ & $51.02 \mathrm{~mA} \mathrm{~cm}^{-2}$ & $0.10 \mathrm{~mL} \mathrm{~s}^{-1}$ & 91 \\
\hline 7 & $1000 \mathrm{~mA}$ & $6 \min$ & $63.78 \mathrm{~mA} \mathrm{~cm}^{-2}$ & $0.10 \mathrm{~mL} \mathrm{~s}^{-1}$ & 81 \\
\hline 8 & 800 mA & $10 \min$ & $51.02 \mathrm{~mA} \mathrm{~cm}^{-2}$ & $0.10 \mathrm{~mL} \mathrm{~s}^{-1}$ & 99 \\
\hline 9 & $800 \mathrm{~mA}$ & $10 \min$ & $51.02 \mathrm{~mA} \mathrm{~cm}^{-2}$ & $0.05 \mathrm{~mL} \mathrm{~s}^{-1}$ & 67 \\
\hline 10 & $800 \mathrm{~mA}$ & $10 \mathrm{~min}$ & $51.02 \mathrm{~mA} \mathrm{~cm}^{-2}$ & $0.15 \mathrm{~mL} \mathrm{~s}^{-1}$ & 95 \\
\hline 11 & 800 mA & $10 \min$ & $51.02 \mathrm{~mA} \mathrm{~cm}^{-2}$ & $0.20 \mathrm{~mL} \mathrm{~s}^{-1}$ & 84 \\
\hline
\end{tabular}

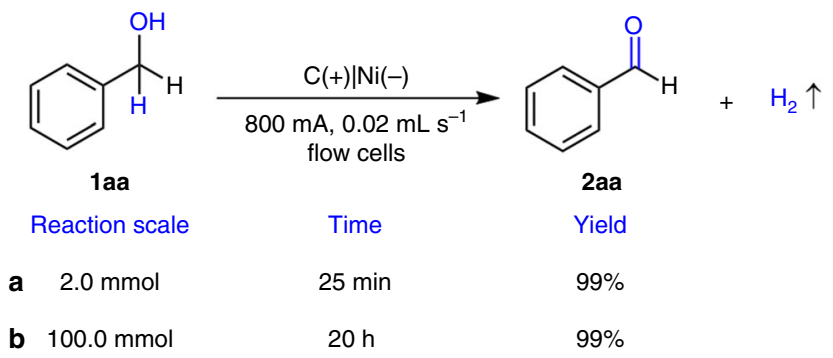

Fig. 2 Slow flow rate of electrochemical oxidation of benzyl alcohol 1aa. a The amount of 1aa is $2.0 \mathrm{mmol}$. b The amount of $\mathbf{1 a a}$ is $100.0 \mathrm{mmol}$

Additionally, we explored the possibility of electrolysis of allylic alcohol 1ap, thus obtaining the corresponding unsaturated aldehyde 2 ap in $64 \%$ yield.

The reaction conditions were subsequently employed to oxidize a range of secondary alcohols (Fig. 4). Excellent results were

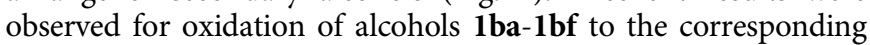
ketones 2ba-2bf in $83-97 \%$ yield. There was no significant difference in the reactivity of primary and secondary alcohols in the continuous-flow reactor. The oxidation of heterocyclic alcohol $\mathbf{l b g}$ proceeded smoothly under $10 \mathrm{~mA}$ cell current condition to afford ketone $\mathbf{2} \mathbf{b g}$ in $70 \%$ yield. Oxidation of allylic alcohols $\mathbf{1 b h}$ $-\mathbf{1 b i}$ afforded the desired ketones in $50-75 \%$ yield. However, aliphatic alcohol was not oxidized smoothly under electrochemical oxidation condition and gave $\mathbf{2 b j}$ in $25 \%$ yield.

This observation led us to explore the selective oxidation of diols 3 and $\mathbf{5}$ as shown in Fig. 5. For both substrates, benzylic hydroxyl groups were oxidized selectively in the presence of aliphatic primary or secondary hydroxyl groups to afford hydroxyl ketones $\mathbf{4}$ and $\mathbf{6}$ in $78 \%$ and $85 \%$ yields, respectively. This oxidation could be complementary to Swern oxidation, which is selective for primary or less steric hindered alcohols ${ }^{65-67}$.

The continuous-flow electrolysis was further extended to pharmaceutical relevant substrates (Fig. 6). Rosuvastatin precursor $1 \mathbf{a q}^{68}$ could be oxidized to the corresponding aldehyde in
$76 \%$ yield within only $10 \mathrm{~min}$, which presented the potential application prospect of this protocol. Fluorenol (1bk) ${ }^{69}$ was oxidized to the corresponding ketones in good yields $(86 \%)$.

The possibility of using water as solvent was also estimated. However, benzaldehyde was obtained in only $82 \%$ yield due to the poor solubility of alcohols in water. Thus, the surfactant was employed and we noted that the ionic surfactant could also be the supporting electrolyte. By using this strategy, benzaldehyde could be prepared in quantitative yield in water (Fig. 7). Six primary alcohols in Fig. 3 and four secondary alcohols in Fig. 4 have been chosen to re-evaluate the yields in the presence of surfactant in pure water. In general, aqueous conditions provided the desired products in comparable yields with our standard conditions, which showed that the combination of water and surfactant would be a good choice for this protocol.

Since the oxidation of alcohol in the anode means the loss of electron, the existence of radical intermediate is highly probable. To gain insight into the reaction mechanism, electron paramagnetic resonance (EPR) experiments were performed by adding the radical spin trapping agent DMPO (5, 5-dimethyl-1-pyrroline $\mathrm{N}$-oxide). No radical signal was detected in the absence of laa (Fig. 8a, blank line). When DMPO was added to the reaction under constant current conditions, a radical signal $\left(g=2.0069, A_{\mathrm{N}}=14.82, A_{\mathrm{H}}=21.42\right)$ was identified (Fig. 8a, red line). According to the fitting result, this radical signal came from benzyl radical captured by DMPO.

No deuterium or ${ }^{18} \mathrm{O}$ was incorporated into benzaldehyde when $\mathrm{H}_{2} \mathrm{O}$ was substituted with $\mathrm{D}_{2} \mathrm{O}$ or $\mathrm{H}_{2}{ }^{18} \mathrm{O}$ in the reaction system (Fig. $8 \mathrm{~b}$ and Supplementary Figs. 5 and 6). This result indicated that water did not react with the intermediate under the reaction conditions. This was in accordance with no over oxidation to benzoic acid was observed even when benzaldehyde was used as starting material for this electrolysis (Supplementary Fig. 8). In addition, no over oxidation of the aldehyde products may also benefit from the fact that no extra base was added in our reaction system.

The influence of the concentration, current, and flow rate to the electrochemical oxidation of benzyl alcohol have been evaluated as shown in Fig. 8. Reaction rate increased with the increasing of the concentration of benzyl alcohol (Fig. 8c). It was 


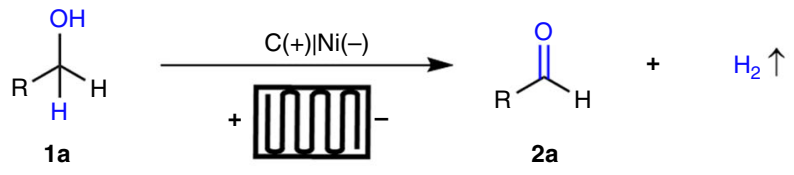<smiles>Cc1ccc(C=O)cc1</smiles>

2ab:99\%<smiles>COc1ccc(C=O)cc1</smiles>

2ag:97\%<smiles>O=Cc1ccc(I)cc1</smiles>

2al: $60 \%{ }^{\mathrm{a}}$<smiles>Cc1ccccc1C=O</smiles>

2ac:99\%<smiles>COc1ccc(C=O)cc1OC</smiles>

2ah:98\%<smiles>O=Cc1ccc([N+](=O)[O-])cc1</smiles>

2am:35\%<smiles>Cc1cccc(C=O)c1</smiles>

2ad:96\%<smiles>O=Cc1ccc(F)cc1</smiles>

2ai:99\%<smiles>O=Cc1cccc2ccccc12</smiles>

2an: $88 \%{ }^{\mathrm{b}}$<smiles>Cc1cc(C)c(C=O)c(C)c1</smiles>

2ae:99\%<smiles>O=Cc1ccc(Cl)cc1</smiles>

2aj:98\%<smiles>O=Cc1cccs1</smiles>

2ao:76\%<smiles>CC(C)(C)c1ccc(C=O)cc1</smiles>

2af:99\%<smiles>O=Cc1ccc(Br)cc1</smiles>

2ak:99\%<smiles>CC(C)=CC=O</smiles>

2ap:64\% ${ }^{\text {b }}$

Fig. 3 Substrate scopes of electrochemical oxidation of primary alcohols. Reaction conditions: carbon paper $(93 \times 93 \times 0.2 \mathrm{~mm})$ anode (contact area $\left.1.6 \mathrm{~cm}^{2}\right)$, Ni plate $(93 \times 93 \times 0.3 \mathrm{~mm})$ cathode (contact area $\left.1.6 \mathrm{~cm}^{2}\right)$, constant current $=800 \mathrm{~mA}$, flow rate $=0.10 \mathrm{~mL} \mathrm{~s}-10 \mathrm{~min}, 1 \mathbf{a}(2.0 \mathrm{mmol})$, ${ }^{n} \mathrm{Bu}_{4} \mathrm{NBF}_{4}(0.20 \mathrm{mmol}), \mathrm{CH}_{3} \mathrm{CN} / \mathrm{H}_{2} \mathrm{O}(1: 1,30 \mathrm{~mL}), \mathrm{N}_{2}$, room temperature, flow cell $\left(2.49 \mathrm{~F} \mathrm{~mol}^{-1}\right)$, isolated yield. a10 mA, $10 \mathrm{~h}$. b10 mA, $20 \mathrm{~h}$

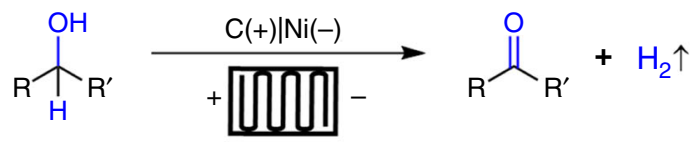

1b<smiles>CC(=O)c1ccccc1</smiles>

2ba: $95 \%$<smiles>O=C(c1ccccc1)c1ccccc1</smiles>

2bf:97\%<smiles>CCC(=O)c1ccccc1</smiles>

$2 \mathrm{bb}: 83 \%$<smiles>CC(=O)c1ccccn1</smiles>

2bg:70\%b<smiles>O=C1CCc2ccccc21</smiles>

2bc: $96 \%$<smiles>O=c1c2ccccc2ccc2ccccc12</smiles>

2bd: $90 \%$<smiles>O=C1C=CCCC1</smiles>

2bi: $75 \%$ a<smiles>O=C(C(=O)c1ccccc1)c1ccccc1</smiles>

2be: $85 \%$ b,c<smiles>CCCCCCC(C)=O</smiles>

2bj:25\%

Fig. 4 Substrate scopes of electrochemical oxidation of secondary alcohols. Reaction conditions: carbon paper $(93 \times 93 \times 0.2 \mathrm{~mm})$ anode (contact area 1.6 $\left.\mathrm{cm}^{2}\right)$, Ni plate $(93 \times 93 \times 0.3 \mathrm{~mm})$ cathode (contact area $\left.1.6 \mathrm{~cm}^{2}\right)$, constant current $=800 \mathrm{~mA}$, flow rate $=0.10 \mathrm{~mL} \mathrm{~s}{ }^{-1}, 10 \mathrm{~min}, \mathbf{1 b}(2.0 \mathrm{mmol}),{ }^{n} \mathrm{Bu} \mathrm{NBF}_{4}$ $(0.20 \mathrm{mmol}), \mathrm{CH}_{3} \mathrm{CN} / \mathrm{H}_{2} \mathrm{O}(1: 1,30 \mathrm{~mL}), \mathrm{N}_{2}$, room temperature, flow cell $\left(2.49 \mathrm{~F} \mathrm{~mol}^{-1}\right)$, isolated yield. a10 mA, $20 \mathrm{~h}$. b10 mA, $10 \mathrm{~h}$. ${ }^{\mathrm{c}} \mathbf{1 b e}$ : benzoin used as starting material

the same that large current meant high reaction rate (Fig. $8 \mathrm{~d}$ ). The reaction rate kept unchanged when the flow rate was larger than $0.10 \mathrm{~mL} \mathrm{~s}^{-1}$ (Supplementary Fig. 7). These results suggested that the electrochemical oxidation was likely to be the ratelimiting step during electrolysis.

On the basis of our mechanistic studies and literature reports $^{41-43}$, a possible mechanism for the oxidation of alcohols to carbonyl functionality is depicted in Fig. 9. The oxidation of benzyl alcohol was initiated by anodic oxidation to afford intermediate $\mathbf{B}$. The consequent deprotonation of the radical cation $\mathbf{B}$ resulted in the formation of benzylic radical $\mathbf{C}$, which has been detected by EPR. The following fast single-electron oxidation and deprotonation of $\mathbf{D}$ produce the desired benzaldehyde (2aa). Lower efficiency of oxidation with electron deficient benzylic alcohols could be explained by considering that electron withdrawing groups destabilized intermediates. In the meantime, water underwent cathodic reduction to generate hydroxide accompanied by releasing hydrogen ${ }^{70}$. The in situ formed hydroxide acted as base to trap the protons. For the whole reaction, no external oxidant was needed, which is in accordance with the idea of green chemistry.

In summary, a direct electrochemical oxidation of alcohols to the corresponding carbonyl compounds has been accomplished efficiently by the continuous-flow reactor just using carbon anode. 


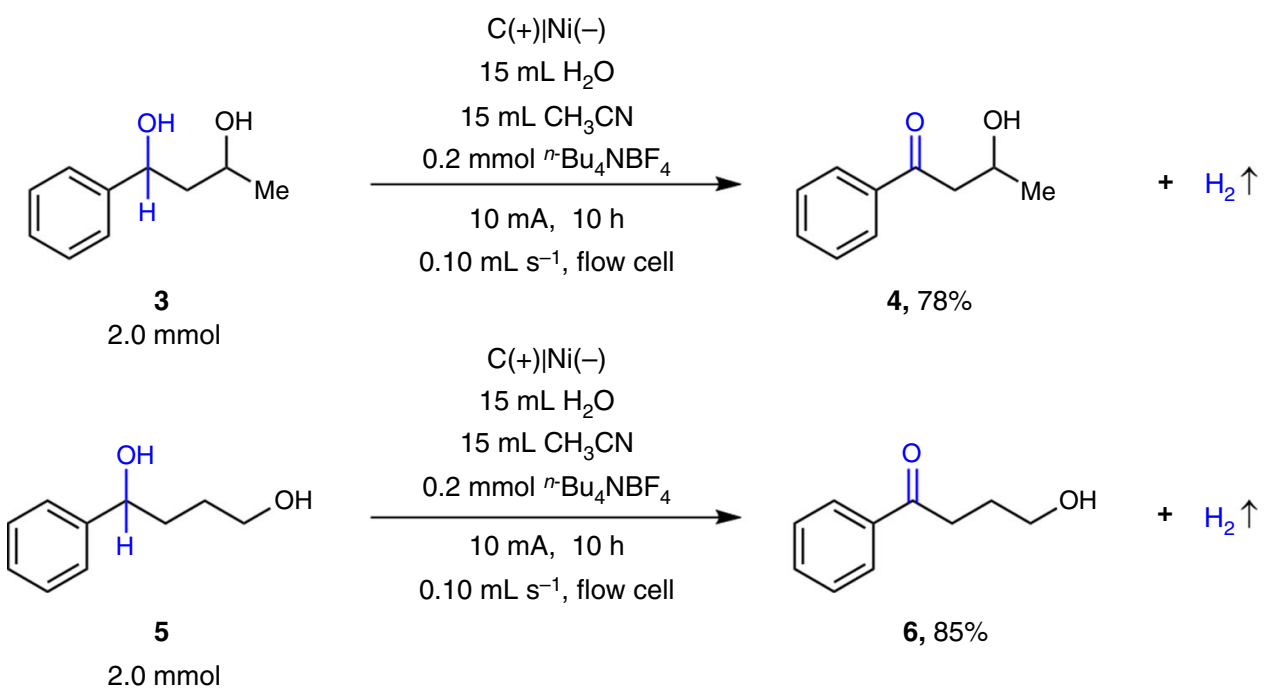

Fig. 5 Selective oxidation of benzylic alcohols in the presence of aliphatic alcohols. a Selective oxidation of 1-phenylbutane-1,3-diol. b Selective oxidation of 1-phenylbutane-1,4-diol<smiles>CC(C)c1nc(N(C)S(C)(=O)=O)nc(-c2ccc(F)cc2)c1C(O)O</smiles>

$1 \mathrm{aq}$

$2.0 \mathrm{mmol}$<smiles>OC1c2ccccc2-c2ccccc21</smiles>

$1 \mathrm{bk}$

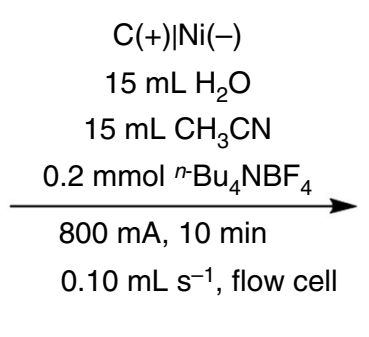

$\mathrm{C}(+) \mid \mathrm{Ni}(-)$

$15 \mathrm{~mL} \mathrm{H}_{2} \mathrm{O}$

$15 \mathrm{~mL} \mathrm{CH} \mathrm{CH}_{3} \mathrm{CN}$

$0.2 \mathrm{mmol}^{n-} \mathrm{Bu}_{4} \mathrm{NBF}_{4}$

$10 \mathrm{~mA}, 10 \mathrm{~h}$

$0.10 \mathrm{~mL} \mathrm{~s}^{-1}$, flow cell<smiles>CC(C)c1nc(N(C)S(C)(=O)=O)nc(-c2ccc([FH+])cc2)c1C=O</smiles>

2aq, $76 \%$<smiles>O=C1c2ccccc2-c2ccccc21</smiles>

2bk, $86 \%$

$2.0 \mathrm{mmol}$

Fig. 6 Electrochemical oxidation of biologically relevant substrates. a Electrochemical oxidation of Rosuvastatin precursor. $\mathbf{b}$ Electrochemical oxidation of 9H-fluoren-9-ol

Reactions were performed without external oxidant, mediator or additive and no over oxidation was observed, which make this method an ideal transformation from alcohols to aldehydes or ketones. Even water can be used as solvent in the presence of surfactant. The reaction conditions have been applied for selective oxidation and biologically relevant substrates. The reaction can be adjusted conveniently from milligram to gram scale based on demand by using the flow set-up. Further research to broaden the substrate scope of alcohol oxidation will be reported in due course.

\section{Methods}

General procedures for the electrolysis in acetonitrile and water. In an ovendried schlenck tube $(100 \mathrm{~mL})$ equipped with a stir bar, alcohol $\mathbf{1 a}(2.0 \mathrm{mmol})$, ${ }^{n} \mathrm{Bu}_{4} \mathrm{NBF}_{4}$ (65.9 mg, $0.2 \mathrm{mmol}$ ) and $\mathrm{CH}_{3} \mathrm{CN} / \mathrm{H}_{2} \mathrm{O}(1: 1,30 \mathrm{~mL}$ ) were added. The flow cell was equipped with carbon paper $(9.3 \mathrm{~cm} \times 9.3 \mathrm{~cm} \times 0.2 \mathrm{~mm})$ as the anode (contact area $\left.1.6 \mathrm{~cm}^{2}\right)$ and nickel plate $(9.3 \mathrm{~cm} \times 9.3 \mathrm{~cm} \times 0.3 \mathrm{~mm})$ as the cathode (contact area $1.6 \mathrm{~cm}^{2}$ ). In order to preclude the possibility that air was involved in the oxidation of alcohol, we flushed the whole system with nitrogen before the direct electrolysis. The reaction mixture was pumped into the electrochemical reactor at the flow rate of $0.10 \mathrm{~mL} \mathrm{~s}^{-1}$ (Supplementary Fig. 1). Method A: A constant current of $800 \mathrm{~mA}$ was employed during the electrolysis under room temperature for $10 \mathrm{~min}$. (Method B: A constant current of $10 \mathrm{~mA}$ was employed during the electrolysis under room temperature for $10 \mathrm{~h}$. Method C: A constant current of $10 \mathrm{~mA}$ was employed during the electrolysis under room temperature for $20 \mathrm{~h}$.) When the reaction was finished, the reaction mixture was washed with water and extracted with dichloromethane $(10 \mathrm{~mL} \times 3)$. The organic layers were combined, dried over $\mathrm{Na}_{2} \mathrm{SO}_{4}$, and concentrated. The pure product was obtained by flash column chromatography on silica gel using petroleum ether and ethyl acetate as the eluent.

General procedures for the electrolysis in water with surfactant. Method D: In an oven-dried schlenck tube $(100 \mathrm{~mL})$ equipped with a stir bar, alcohol 1a $(2.0$ $\mathrm{mmol}), N, N, N$-trimethylhexadecan-1-ammonium sulfate $(69.6 \mathrm{mg}, 0.10 \mathrm{mmol})$ and $\mathrm{H}_{2} \mathrm{O}(15 \mathrm{~mL})$ were added. The flow cell was equipped with carbon paper $(9.3 \mathrm{~cm} \times$ $9.3 \mathrm{~cm} \times 0.2 \mathrm{~mm})$ as the anode (contact area $\left.1.6 \mathrm{~cm}^{2}\right)$ and nickel plate $(9.3 \mathrm{~cm} \times$ $9.3 \mathrm{~cm} \times 0.3 \mathrm{~mm}$ ) as the cathode (contact area $1.6 \mathrm{~cm}^{2}$ ). In order to preclude the 
<smiles>[R]C(=O)[18F]</smiles>

1

2<smiles>O=Cc1ccccc1</smiles>

2aa:99\% $\left(82 \%{ }^{a}\right)$<smiles>O=Cc1cccs1</smiles>

2ao:67\%<smiles>Cc1ccccc1C=O</smiles>

2ac: $99 \%$<smiles>CC(=O)c1ccccc1</smiles>

2ba: $95 \%$<smiles>CC(C)(C)c1ccc(C=O)cc1</smiles>

2af:90\%<smiles>CC(=O)c1ccccn1</smiles>

2bg: $66 \%{ }^{\mathrm{c}}$<smiles>COc1ccc(C=O)cc1</smiles>

2ag:95\%<smiles>O=C1C=CCCC1</smiles>

2bi: $70 \%{ }^{b}$<smiles>O=Cc1ccc(F)cc1</smiles>

2ai:80\%<smiles>CCCCCCC(C)=O</smiles>

2bj:27\%

Fig. 7 Substrate scopes of electrochemical oxidation of alcohols in water. Reaction conditions: carbon paper $(93 \times 93 \times 0.2 \mathrm{~mm})$ anode (contact area $\left.1.6 \mathrm{~cm}^{2}\right)$, Ni plate $(93 \times 93 \times 0.3 \mathrm{~mm})$ cathode (contact area $\left.1.6 \mathrm{~cm}^{2}\right)$, constant current $=800 \mathrm{~mA}$, flow rate $=0.10 \mathrm{~mL} \mathrm{~s}-1,10 \mathrm{~min}, 1(2.0 \mathrm{mmol}), \mathrm{N}, \mathrm{N}, \mathrm{N}$ trimethylhexadecan-1-ammonium sulfate $(0.10 \mathrm{mmol}), \mathrm{H}_{2} \mathrm{O}(15 \mathrm{~mL}), \mathrm{N}_{2}$, room temperature, flow cell $\left(2.49 \mathrm{~F} \mathrm{~mol}^{-1}\right)$, isolated yield. a LiClO ${ }_{4}$ instead of $\mathrm{N}_{1} \mathrm{~N}$, $\mathrm{N}$-trimethylhexadecan-1-ammonium sulfate. ${ }^{b} 10 \mathrm{~mA}, 20 \mathrm{~h} .{ }^{\mathrm{c}} 10 \mathrm{~mA}, 10 \mathrm{~h}$

a
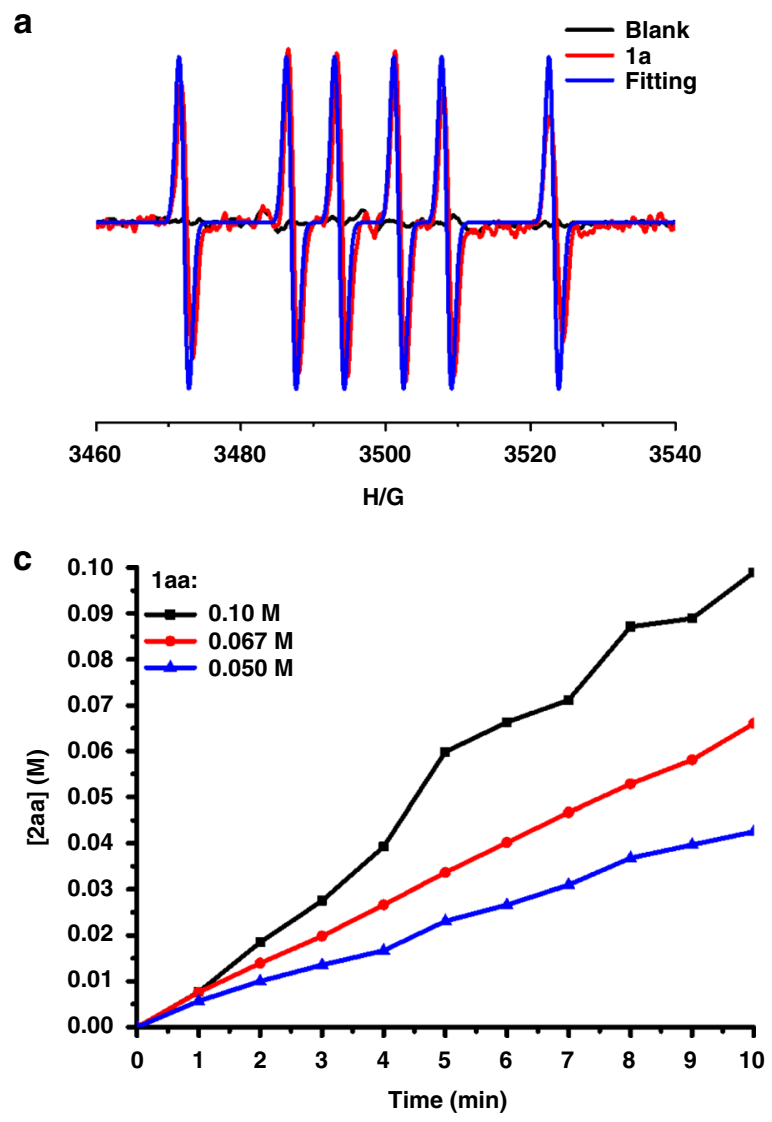

b

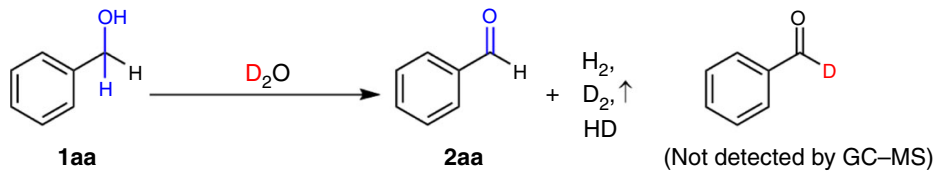<smiles></smiles>

1aa (Not detected by GC-MS)

Fig. 8 Mechanistic studies experiments. a EPR results of benzyl alcohol oxidation. $\mathbf{b} \mathrm{D}_{2} \mathrm{O}$ and $\mathrm{H}_{2}{ }^{18} \mathrm{O}$ labeling experiments. c Kinetic profiles under different concentrations of 1aa. d Kinetic profiles under different current

possibility that air was involved in the oxidation of alcohol, we flushed the whole system with nitrogen before the direct electrolysis. The reaction mixture was pumped into the electrochemical reactor in a flow rate of $0.10 \mathrm{~mL} \mathrm{~s}^{-1}$ (Supplementary Fig. 1). A constant current of $800 \mathrm{~mA}$ was employed during the electrolysis under room temperature for $10 \mathrm{~min}$. When the reaction was finished, the reaction mixture was washed with water and extracted with dichloromethane $(10 \mathrm{~mL} \times 3)$. The organic layers were combined, dried over $\mathrm{Na}_{2} \mathrm{SO}_{4}$, and concentrated. The pure product was obtained by flash column chromatography on silica gel using petroleum ether and ethyl acetate as the eluent.

\section{Data availability}

The authors declare that the data supporting the findings of this study are available within the article and its Supplementary Information files. 


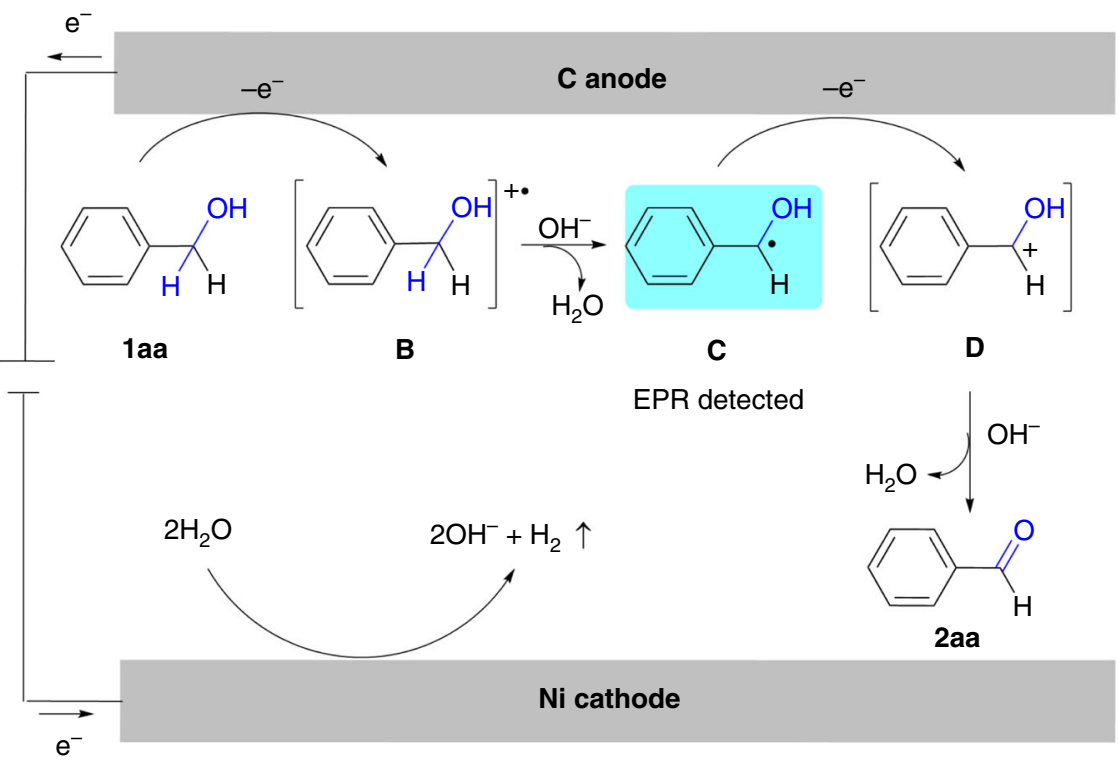

Fig. 9 Proposed mechanism of benzyl alcohol electrochemical oxidation. A tentative reaction mechanism involves anodic oxidation of benzyl alcohol to afford intermediate B, deprotonation, single electron oxidation and deprotonation to form the desired benzaldehyde (2aa). Water underwent cathodic reduction to generate hydroxide accompanied by releasing hydrogen

Received: 21 November 2018 Accepted: 6 June 2019

Published online: 26 June 2019

\section{References}

1. Tojo, G. \& Fernandez, M. Basic Reactions in Organic Synthesis: Oxidation of Alcohols to Aldehydes and Ketones. (Springer, New York, 2010).

2. March, J. in March's Advanced Organic Chemistry: Reactions, Mechanisms and Structures, 7th edn, (ed. Smith, M. B.) 1442-1452 (Wiley-VCH, Weinheim, 2013).

3. Constable, D. J. C. et al. Key green chemistry research areas-a perspective from pharmaceutical manufacturers. Green Chem. 9, 411-420 (2007).

4. Sheldon, R. A., Arends, I., Ten Brink, G. J. \& Dijksman, A. Green, catalytic oxidations of alcohols. Acc. Chem. Res. 35, 774-781 (2002).

5. Faisca Phillips, A. M., Pombeiro, A. J. L. \& Kopylovich, M. N. Recent advances in cascade reactions initiated by alcohol oxidation. Chem CatChem 9, 217-246 (2017).

6. Siddiki, S. M. A. H., Toyao, T. \& Shimizu, K. -i Acceptorless dehydrogenative coupling reactions with alcohols over heterogeneous catalysts. Green Chem. 20, 2933-2952 (2018).

7. Anastas, P. \& Warner, J. Green Chemistry: Theory and Practice (Oxford University Press, New York, 1998).

8. Takemoto, T., Yasuda, K. \& Ley, S. V. Solid-supported reagents for the oxidation of aldehydes to carboxylic acids. Synlett 10, 1555-1556 (2001).

9. Lou, J. D. \& Xu, Z. N. Selective oxidation of primary alcohols with chromium trioxide under solvent free conditions. Tetrahedron Lett. 43, 6095-6097 (2002).

10. Kumar, A., Jain, N. \& Chauhan, S. M. S. Oxidation of benzylic alcohols to carbonyl compounds with potassium permanganate in ionic liquids. Synth. Commun. 34, 2835-2842 (2004).

11. Gonzalez-Nunez, M. E., Mello, R., Olmos, A., Acerete, R. \& Asensio, G. Oxidation of alcohols to carbonyl compounds with $\mathrm{CrO}_{3}$ center dot $\mathrm{SiO}_{2}$ in supercritical carbon dioxide. J. Org. Chem. 71, 1039-1042 (2006).

12. Hampton, P. D., Whealon, M. D., Roberts, L. M., Yaeger, A. A. \& Boydson, R. Continuous organic synthesis in a spinning tube-in-tube reactor: TEMPOcatalyzed oxidation of alcohols by hypochlorite. Org. Process Res. Dev. 12, 946-949 (2008).

13. De Crisci, A. G., Chung, K., Oliver, A. G., Solis-Ibarra, D. \& Waymouth, R. M. Chemoselective oxidation of polyols with chiral palladium catalysts. Organometallics 32, 2257-2266 (2013).

14. Manzini, S., Urbina-Blanco, C. A. \& Nolan, S. P. Chemoselective oxidation of secondary alcohols using a ruthenium phenylindenyl complex. Organometallics 32, 660-664 (2013).

15. Jing, Y., Daniliuc, C. G. \& Studer, A. Direct conversion of alcohols to $\alpha$-chloro aldehydes and a-chloro ketones. Org. Lett. 16, 4932-4935 (2014).
16. Zheng, N. \& Stucky, G. D. Promoting gold nanocatalysts in solvent-free selective aerobic oxidation of alcohols. Chem. Commun. 3862-3864 (2007).

17. Jiang, B., Feng, Y. \& Ison, E. A. Mechanistic investigations of the iridium(III)catalyzed aerobic oxidation of primary and secondary alcohols. J. Am. Chem. Soc. 130, 14462-14464 (2008).

18. Parmeggiani, C. \& Cardona, F. Transition metal based catalysts in the aerobic oxidation of alcohols. Green Chem. 14, 547-564 (2012).

19. Shi, Z., Zhang, C., Tang, C. \& Jiao, N. Recent advances in transition-metal catalyzed reactions using molecular oxygen as the oxidant. Chem. Soc. Rev. 41, 3381-3430 (2012)

20. Ryland, B. L. \& Stahl, S. S. Practical aerobic oxidations of alcohols and amines with homogeneous copper/TEMPO and related catalyst systems. Angew. Chem. Int. Ed. 53, 8824-8838 (2014).

21. Gunasekaran, N. Aerobic oxidation catalysis with air or molecular oxygen and ionic liquids. Adv. Synth. Catal. 357, 1990-2010 (2015)

22. Crotti, C. \& Farnetti, E. Selective oxidation of glycerol catalyzed by iron complexes. J. Mol. Catal. A: Chem. 396, 353-359 (2015).

23. Zhang, J., Gandelman, M., Shimon, L. J. W., Rozenberg, H. \& Milstein, D. Electron-rich, bulky ruthenium PNP-type complexes. Acceptorless catalytic alcohol dehydrogenation. Organometallics 23, 4026-4033 (2004).

24. Nielsen, M. et al. Efficient hydrogen production from alcohols under mild reaction conditions. Angew. Chem. Int. Ed. 50, 9593-9597 (2011).

25. Kawahara, R., Fujita, K. -i \& Yamaguchi, R. Dehydrogenative oxidation of alcohols in aqueous media using water-soluble and reusable $\mathrm{Cp}^{\star} \mathrm{Ir}$ catalysts bearing a functional bipyridine ligand. J. Am. Chem. Soc. 134, 3643-3646 (2012).

26. Kawahara, R., Fujita, K. -i \& Yamaguchi, R. Cooperative catalysis by iridium complexes with a bipyridonate ligand: versatile dehydrogenative oxidation of alcohols and reversible dehydrogenation-hydrogenation between 2-propanol and acetone. Angew. Chem. Int. Ed. 51, 12790-12794 (2012).

27. Nielsen, M. et al. Low-temperature aqueous-phase methanol dehydrogenation to hydrogen and carbon dioxide. Nature 495, 85 (2013).

28. Gunanathan, C. \& Milstein, D. Applications of acceptorless dehydrogenation and related transformations in chemical synthesis. Science 341, 1229712 (2013).

29. Song, H., Kang, B. \& Hong, S. H. Fe-catalyzed acceptorless dehydrogenation of secondary benzylic alcohols. ACS Catal. 4, 2889-2895 (2014).

30. Fujita, K. -i, Kawahara, R., Aikawa, T. \& Yamaguchi, R. Hydrogen production from a methanol-water solution catalyzed by an anionic iridium complex bearing a functional bipyridonate ligand under weakly basic conditions. Angew. Chem. Int. Ed. 54, 9057-9060 (2015).

31. Liu, Y., Zhang, P., Tian, B. \& Zhang, J. Core-shell structural CdS@SnO nanorods with excellent visible-light photocatalytic activity for the selective oxidation of benzyl alcohol to benzaldehyde. ACS Appl. Mater. Interfaces 7, 13849-13858 (2015).

32. Zhao, L. -M. et al. Photocatalysis with quantum dots and visible light: selective and efficient oxidation of alcohols to carbonyl compounds through a radical relay process in water. Angew. Chem. Int. Ed. 56, 3020-3024 (2017). 
33. Bianchini, C. \& Shen, P. K. Palladium-based electrocatalysts for alcohol oxidation in half cells and in direct alcohol fuel cells. Chem. Rev. 109, 4183-4206 (2009).

34. Hickey, D. P., McCammant, M. S., Giroud, F., Sigman, M. S. \& Minteer, S. D. Hybrid enzymatic and organic electrocatalytic cascade for the complete oxidation of glycerol. J. Am. Chem. Soc. 136, 15917-15920 (2014).

35. Trincado, M., Banerjee, D. \& Gruetzmacher, H. Molecular catalysts for hydrogen production from alcohols. Energy Environ. Sci. 7, 2464-2503 (2014).

36. Cha, H. G. \& Choi, K.-S. Combined biomass valorization and hydrogen production in a photoelectrochemical cell. Nat. Chem. 7, 328-333 (2015).

37. Rafiee, M., Miles, K. C. \& Stahl, S. S. Electrocatalytic alcohol oxidation with TEMPO and bicyclic nitroxyl derivatives: driving force trumps steric effects. J. Am. Chem. Soc. 137, 14751-14757 (2015).

38. Badalyan, A. \& Stahl, S. S. Cooperative electrocatalytic alcohol oxidation with electron-proton-transfer mediators. Nature 535, 406-410 (2016).

39. Choi, Y., Sinev, I., Mistry, H., Zegkinoglou, I. \& Roldan Cuenya, B. Probing the dynamic structure and chemical state of Au nanocatalysts during the electrochemical oxidation of 2-propanol. ACS Catal. 6, 3396-3403 (2016).

40. Nutting, J. E., Rafiee, M. \& Stahl, S. S. Tetramethylpiperidine N-Oxyl (TEMPO), phthalimide N-Oxyl (PINO), and related N-Oxyl species: electrochemical properties and their use in electrocatalytic reactions. Chem. Rev. 118, 4834-4885 (2018).

41. Lund, H. Electroorganic preparations II. Oxidation carbinols. Acta Chem. Scand. 11, 491-498 (1957).

42. Mayeda, E. A., Miller, L. L. \& Wolf, J. F. Electrooxidation of benzylic ethers, esters, alcohols, and phenyl epoxides. J. Am. Chem. Soc. 94, 6812-6816 (1972).

43. Mayeda, E. A. Anodic cleavages of secondary and tertiary alkylphenylcarbinols. J. Am. Chem. Soc. 97, 4012-4015 (1975).

44. Plutschack, M. B., Pieber, B., Gilmore, K. \& Seeberger, P. H. The Hitchhiker's guide to flow chemistry(II). Chem. Rev. 117, 11796-11893 (2017).

45. Atobe, M., Tateno, H. \& Matsumura, Y. Applications of flow microreactors in electrosynthetic processes. Chem. Rev. 118, 4541-4572 (2018).

46. Pletcher, D., Green, R. A. \& Brown, R. C. D. Flow electrolysis cells for the synthetic organic chemistry laboratory. Chem. Rev. 118, 4573-4591 (2018)

47. Bebelis, S. et al. Highlights during the development of electrochemical engineering. Chem. Eng. Res. Des. 91, 1998-2020 (2013).

48. Gütz, C., Stenglein, A. \& Waldvogel, S. R. Highly modular flow cell for electroorganic synthesis. Org. Process Res. Dev. 21, 771-778 (2017).

49. Laudadio, G., de Smet, W., Struik, L., Cao, Y. \& Noël, T. Design and application of a modular and scalable electrochemical flow microreactor. $J$. Flow. Chem. 8, 157-165 (2018).

50. Fol-gueiras-Amador, A. A. \& Wirth, T. Perspectives in flow electrochemistry. J. Flow. Chem. 7, 94-95 (2017).

51. Folgueiras-Amador, A. A., Philipps, K., Guilbaud, S., Poelakker, J. \& Wirth, T. An easy-to-machine electrochemical flow microreactor: efficient synthesis of isoindolinone and flow functionalization. Angew. Chem. Int. Ed. 56, 15446-15450 (2017).

52. Arai, K. \& Wirth, T. Rapid electrochemical deprotection of the isonicotinyloxycarbonyl group from carbonates and thiocarbonates in a microfluidic reactor. Org. Process Res. Dev. 18, 1377-1381 (2014).

53. Horcajada, R., Okajima, M., Suga, S. \& Yoshida, J. Microflow electroorganic synthesis without supporting electrolyte. Chem. Commun. 1303-1305 (2005).

54. Green, R. A., Pletcher, D., Leach, S. G. \& Brown, R. C. D. N-Heterocyclic carbene-mediated microfluidic oxidative electrosynthesis of amides from aldehydes. Org. Lett. 18, 1198-1201 (2016).

55. Laudadio, G. et al. An environmentally benign and selective electrochemical oxidation of sulfides and thiols in a continuous-flow microreactor. Green Chem. 19, 4061-4066 (2017).

56. Arai, K., Watts, K. \& Wirth, T. Difluoro- and trifluoromethylation of electrondeficient alkenes in an electrochemical microreactor. ChemistryOpen 3, 23-28 (2014).

57. Kabeshov, M. A., Musio, B., Murray, P. R. D., Browne, D. L. \& Ley, S. V. Expedient preparation of nazlinine and a small library of indole alkaloids using flow electrochemistry as an enabling technology. Org. Lett. 16, 4618-4621 (2014).

58. Kashiwagi, T., Elsler, B., Waldvogel, S. R., Fuchigami, T. \& Atobe, M. Reaction condition screening by using electrochemical microreactor: application to anodic phenol-arene $\mathrm{C}, \mathrm{C}$ cross-coupling reaction in high acceptor number media. J. Electrochem. Soc. 160, G3058-G3061 (2013).

59. Tateno, H., Matsumura, Y., Nakabayashi, K., Senboku, H. \& Atobe, M. Development of a novel electrochemical carboxylation system using a microreactor. RSC Adv. 5, 98721-98723 (2015).

60. HillCousins, J. T. et al. TEMPO-mediated electrooxidation of primary and secondary alcohols in a microfluidic electrolytic cell. ChemSusChem 5, 326-331 (2012).

61. Xu, F., Qian, X. -Y., Li, Y. -J. \& Xu, H. -C. Synthesis of 4H-1,3-benzoxazines via metal- and oxidizing reagent-free aromatic $\mathrm{C}-\mathrm{H}$ oxygenation. Org. Lett. 19, 6332 (2017).
62. Folgueiras-Amador, A. A., Qian, X. -Y., Xu, H. -C. \& Wirth, T. Catalystand supporting-electrolyte-free electrosynthesis of benzothiazoles and thiazolopyridines in continuous flow. Chem. Eur. J. 24, 487-491 (2018).

63. Huang, C., Qian, X. -Y. \& Xu, H. -C. Continuous-flow electrosynthesis of benzofused S-heterocycles by dehydrogenative C-S cross-coupling. Angew. Chem. Int. Ed. 58, 6650-6653 (2019).

64. Hosokawa, Y. -Y., Hakamata, H., Murakami, T. \& Kusu, F. Electrosynthesis of cholesta-4,6-dien-3-one from cholesterol on a laboratory synthetic scale. Tetrahedron Lett. 51, 129-132 (2010).

65. Huang, S. L., Omura, K. \& Swern, D. Oxidation of sterically hindered alcohols to carbonyls with dimethyl sulfoxide-trifluoracetic anhydride. J. Org. Chem. 41, 3329-3331 (1976).

66. Huang, S. L., Omura, K. \& Swern, D. Further studies on the oxidation of alcohols to carbonyl compounds by dimethyl sulfoxide/trifluoroacetic anhydride. Synthesis 4, 297-299 (1978).

67. Mancuso, A. J., Huang, S. L. \& Swern, D. Oxidation of long-chain and related alcohols to carbonyls by dimethyl sulfoxide "activated" by oxalyl chloride. $J$. Org. Chem. 43, 2480-2482 (1978).

68. Das, A. \& Stahl, S. S. Noncovalent immobilization of molecular electrocatalysts for chemical synthesis: efficient electrochemical alcohol oxidation with a pyrene-TEMPO conjugate. Angew. Chem. Int. Ed. 56, 8892-8897 (2017).

69. Li, H. et al. Characterization of a new class of androgen receptor antagonists with potential therapeutic application in advanced prostate cancer. Mol. Cancer Ther. 12, 2425-2435 (2013).

70. Wang, P., Tang, S. \& Lei, A. Electrochemical intramolecular dehydrogenative C-S bond formation for the synthesis of benzothiazoles. Green Chem. 19, 2092-2095 (2017).

\section{Acknowledgements}

This work was supported by the National Natural Science Foundation of China $(21390402,21520102003,21272180)$ and the Natural Science Foundation of Hubei Province (2017CFA010, 2016CFB571). The Program of Introducing Talents of Discipline to Universities of China (111 Program) is also appreciated. The numerical calculations in this paper have been done on the supercomputing system in the Supercomputing Center of Wuhan University. We thank Prof. Xuefeng Li for providing surfactant as gift.

\section{Author contributions}

D.W., P.D. and S.-C.W. performed and analyzed experiments. A.L., Y.-H.C., H.Z. and D.W. conceived the project and designed the experiments. A.L., Y.-H.C., H.Z. and D.W wrote the manuscript. All the authors discussed the results and commented on the manuscript.

\section{Additional information}

Supplementary Information accompanies this paper at https://doi.org/10.1038/s41467019-10928-0.

Competing interests: The authors declare no competing interests.

Reprints and permission information is available online at http://npg.nature.com/ reprintsandpermissions/

Peer review information: Nature Communications thanks Carlos Ponce de Leon and other anonymous reviewer(s) for their contribution to the peer review of this work.

Publisher's note: Springer Nature remains neutral with regard to jurisdictional claims in published maps and institutional affiliations.

Open Access This article is licensed under a Creative Commons Attribution 4.0 International License, which permits use, sharing, adaptation, distribution and reproduction in any medium or format, as long as you give appropriate credit to the original author(s) and the source, provide a link to the Creative Commons license, and indicate if changes were made. The images or other third party material in this article are included in the article's Creative Commons license, unless indicated otherwise in a credit line to the material. If material is not included in the article's Creative Commons license and your intended use is not permitted by statutory regulation or exceeds the permitted use, you will need to obtain permission directly from the copyright holder. To view a copy of this license, visit http://creativecommons.org/ licenses/by/4.0/

(C) The Author(s) 2019 